\title{
Evaluation of amplification targets for the specific detection of Bordetella pertussis using real-time polymerase chain reaction
}

\author{
Mohammad Rubayet Hasan PhD ${ }^{1,2}$, Rusung Tan MD PhD FRCPC $1,2,3$, Ghada N Al-Rawahi MD FRCPC ${ }^{1,2}$, \\ Eva Thomas MD PhD FRCPC ${ }^{1,2}$, Peter Tilley MD FRCPC ${ }^{1,2}$
}

\begin{abstract}
MR Hasan, R Tan, GN Al-Rawahi, E Thomas, P Tilley. Evaluation of amplification targets for the specific detection of Bordetella pertussis using real-time polymerase chain reaction. Can J Infect Dis Med Microbiol 2014;25(4):217-221.
\end{abstract}

BACKGROUND: Bordetella pertussis infections continue to be a major public health challenge in Canada. Polymerase chain reaction (PCR) assays to detect $B$ pertussis are typically based on the multicopy insertion sequence IS481, which offers high sensitivity but lacks species specificity.

METHODS: A novel B pertussis real-time PCR assay based on the porin gene was tested in parallel with several previously published assays that target genes such as IS481, ptx-promoter, pertactin and a putative thialase. The assays were evaluated using a reference panel of common respiratory bacteria including different Bordetella species and 107 clinical nasopharyngeal specimens. Discrepant results were confirmed by sequencing the PCR products.

RESULTS: Analytical sensitivity was highest for the assay targeting the IS481 element; however, the assay lacked specificity for B pertussis in the reference panel and in the clinical samples. False-positive results were also observed with assays targeting the ptx-promoter and pertactin genes. A PCR assay based on the thialase gene was highly specific but failed to detect all reference strains of $B$ pertussis. However, a novel assay targeting the porin gene demonstrated high specificity for $B$ pertussis both in the reference panel and in clinical samples and, based on sequenceconfirmed results, correctly predicted all $B$ pertussis-positive cases in clinical samples. According to Probit regression analysis, the 95\% detection limit of the new assay was 4 colony forming units/reaction.

CONCLUSION: A novel porin assay for B pertussis demonstrated superior performance and may be useful for improved molecular detection of $B$ pertussis in clinical specimens.

Key Words: Bordetella pertussis; IS481 element; Pertactin gene; Porin gene; Ptx-promoter; Real-time PCR

$\mathrm{D}^{2}$ espite high vaccine coverage, the number of reported cases of pertussis (whooping cough) has increased in recent years in the United States and Canada $(1,2)$. Whooping cough is caused by the most widely known Bordetella species, Bordetella pertussis. For diagnosis, polymerase chain reaction (PCR)-based methods to detect $B$ pertussis in nasopharyngeal swabs or aspirates from patients with suspected pertussis are now commonly used due to their improved sensitivity and decreased turnaround time compared with bacterial culture (3). Currently, the most common PCR target is the multicopy insertion sequence IS481, which is repeated more than 200 times in the B pertussis genome (4). IS481 PCR assays are widely used because of their high sensitivity. However, these assays lack specificity because the IS481 sequence is also present in the genomes of other Bordetella species (eg,

\section{L'évaluation des cibles d'amplification pour déceler le Bordetella pertussis au moyen de la méthode de réaction en chaîne de la polymérase en temps réel}

HISTORIQUE : Les infections à Bordetella pertussis continuent d'être un important problème de santé publique au Canada. Les méthodes de réaction en chaîne de la polymérase (PCR) pour déceler le B pertussis sont habituellement fondées sur la séquence d'insertion multicopie IS481, dont la sensibilité élevée, mais dont la spécificité d'espèce est inexistante.

MÉTHODOLOGIE : Une nouvelle méthode PCR en temps réel du B pertussis fondée sur le gène de porine a été mise à l'essai parallèlement à plusieurs méthodes déjà publiées qui ciblent des gènes comme l'IS481, le promoteur de ptx, la pertactine et une thialase éventuelle. Les méthodes ont été évaluées à l'aide d'un groupe de référence de bactéries respiratoires communes, y compris diverses espèces de Bordetella et 107 échantillons nasopharyngés cliniques. Les résultats contradictoires ont été confirmés par séquençage des produits de PCR.

RÉSULTATS : La méthode visant l'élément IS481 avait la sensibilité analytique la plus élevée, mais manquait de spécificité pour le B pertussis dans le groupe de référence et les échantillons cliniques. Les méthodes ciblant les gènes du promoteur de ptx et de la perctatine ont également donné des résultats faux positifs. Une méthode de PCR fondée sur le gène thialase était hautement spécifique, mais ne décelait pas toutes les souches de référence du $B$ pertussis. Cependant, une nouvelle méthode ciblant le gène de porine a démontré une forte spécificité au $B$ pertussis, à la fois dans le groupe de référence et dans les échantillons cliniques et, d'après les résultats confirmés par séquençage, prédit correctement tous les cas positifs au $B$ pertussis dans les échantillons cliniques. D'après l'analyse de régression Probit, la limite de détection de $95 \%$ de la nouvelle méthode était de quatre unités formant colonies par réaction.

CONCLUSION : Une nouvelle méthode faisant appel à la porine pour déceler le $B$ pertussis donne un rendement supérieur et peut être utile pour améliorer la détection moléculaire du B pertussis dans des échantillons cliniques.

${ }^{1}$ Division of Microbiology, Virology and Infection Control, Department of Pathology, Children's and Women's Health Centre of BC; ${ }^{2}$ Department of Pathology and Laboratory Medicine, University of British Columbia, Vancouver, British Columbia; ${ }^{3}$ Sidra Medical and Research Center,

Doha, Qatar

Correspondence: Dr Mohammad Rubayet Hasan, Microbiology Laboratory, BC Children's $\mathcal{G}$ Women's Hospitals, Room 2F59A,

4500 Oak Street, Vancouver, British Columbia V6H 3N1. Telephone 604-875-2345 ext 5283, fax 604-875-3777, e-mail rubayet.hasan@cw.bc.ca

OPEN $\bigcirc$ ACCESS

This open-access article is distributed under the terms of the Creative Commons Attribution Non-Commercial License (CC BY-NC) (http:// creativecommons.org/licenses/by-nc/4.0/), which permits reuse, distribution and reproduction of the article, provided that the original work is properly cited and the reuse is restricted to noncommercial purposes. For commercial reuse, contact support@pulsus.com 
TABLE 1

Description of primers and probes used in the present study

\begin{tabular}{|c|c|c|c|c|c|c|}
\hline Assay & Target gene & Genome position* & Primer/probe & Sequence $\left(5^{\prime}-3^{\prime}\right)$ & Working concentration & Reference \\
\hline \multirow[t]{3}{*}{ IS481 } & \multirow{3}{*}{$\begin{array}{l}\text { Bordetella pertussis insertion } \\
\text { sequence IS481 }\end{array}$} & $58491-58511^{\dagger}$ & Forward & CCGAACCGGATTTGAGAAAC & $330 \mathrm{nM}$ & \multirow[t]{3}{*}{11} \\
\hline & & $58413-58432^{\dagger}$ & Reverse & TAGGAAGGTCAATCGGGCAT & $330 \mathrm{nM}$ & \\
\hline & & $58435-58456^{\dagger}$ & Probe $^{\ddagger}$ & CCGGCCGGATGAACACCCATAA & $200 \mathrm{nM}$ & \\
\hline \multirow{2}{*}{ OMP } & \multirow{2}{*}{$\begin{array}{c}\text { B pertussis/B parapertussis } \\
\text { gene for a porin protein }\end{array}$} & $3658866-3658884 \pi$ & Forward $2^{\S}$ & TGAGGTCGGGCGAATCGTC & $240 \mathrm{nM}$ & \multirow{2}{*}{15} \\
\hline & & $869040-869066$ & Reverse ${ }^{\S}$ & TTGTTGGTAAGTTGCAACATCCTGTCC & $240 \mathrm{nM}$ & \\
\hline \multirow[t]{2}{*}{ BPTP } & \multirow{2}{*}{$\begin{array}{l}\text { B pertussis pertussis toxin } \\
\text { gene, promoter region }\end{array}$} & 3988078-3988098 & Forward§ & TTCGTCGTACAAAACCCTCGA & $330 \mathrm{nM}$ & \multirow[t]{2}{*}{12} \\
\hline & & 3988101-3988114 & Probe ${ }^{\star *}$ & CTTCCGTACATCCC & $200 \mathrm{nM}$ & \\
\hline \multirow[t]{3}{*}{ PRN } & \multirow[t]{3}{*}{ B pertussis pertactin gene } & 1098189-1098206 & Forward & TGCCGACTGGAACAACCA & $300 \mathrm{nM}$ & \multirow[t]{3}{*}{14} \\
\hline & & $1098243-1098261$ & Reverse & GTCGGAGCCCTGGATATGG & $300 \mathrm{nM}$ & \\
\hline & & $1098211-1098232$ & Probe $\S$ & ATCGTCAAGACCGGTGAGCGCC & $66 \mathrm{nM}$ & \\
\hline \multirow[t]{2}{*}{ BP283 } & \multirow{2}{*}{$\begin{array}{l}\text { Putative thiolase gene } \\
\text { (BP0026) }\end{array}$} & $30021-30040$ & Forward & CAGGCACAGCACGTATTGCG & $330 \mathrm{nM}$ & \multirow[t]{2}{*}{13} \\
\hline & & $30104-30126$ & Reverse & GACGATTACCAGCGAGATTACGA & $330 \mathrm{nM}$ & \\
\hline PT-P & $\begin{array}{l}\text { B pertussis pertussis toxin } \\
\text { gene, promoter region }\end{array}$ & 3988080-3988098 & Probe ${ }^{\star *}$ & CGTCGTACAAAACCCTCGA & $200 \mathrm{nM}$ & $\begin{array}{l}\text { Present } \\
\text { study }\end{array}$ \\
\hline \multirow[t]{3}{*}{ POR } & \multirow{3}{*}{$\begin{array}{l}\text { B pertussis gene for a porin } \\
\text { protein (BPTD_0837) }\end{array}$} & $868978-869001^{\dagger}$ & Forward§ & TGAACCATGCATACAACCTATTGA & $330 \mathrm{nM}$ & \multirow{3}{*}{$\begin{array}{l}\text { Present } \\
\text { study }\end{array}$} \\
\hline & & 869026-869046 & Reverse§ & CCTGTCCCCTTAATCCGGAAT & $330 \mathrm{nM}$ & \\
\hline & & $869003-869024$ & Probe $^{\ddagger}$ & TCTTCACAGTTAGCCCGCGCGC & $200 \mathrm{nM}$ & \\
\hline
\end{tabular}

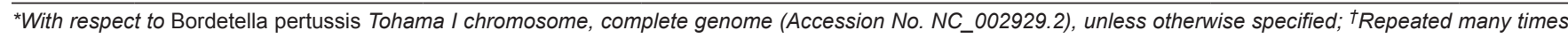
(one position shown); $¥ 5$ '-end labelled with 6-carboxyfluorescein (FAM) and 3'-end labelled with Black Hole Quencher 1 (BHQ1); §Primers also used for sequencing; IWith respect to Bordetella parapertussis 12822 chromosome, complete genome (Accession No. NC_002928.3); **5'-end labelled with 6-carboxyfluorescein (FAM) and 3'-end labelled with MGB non-fluorescence quencher. BPTP Bordetella parapertussis toxin promoter; OMP Outer membrane porin protein; POR Porin; PRN Pertactin; PT-P Pertussis toxin promoter

interventions that are generally unnecessary for nonpertussis Bordetella strains. Moreover, proper identification of pertussis cases enables more accurate assessment and enumeration of cases of vaccine failure - an issue of considerable public health importance.

Due to concerns about the false-positive results from IS481 PCR assays produced by nonpertussis Bordetella species, suggestions have been made to use multitarget PCR assays for definitive diagnosis of pertussis $(10,11)$. These strategies, however, significantly increase workload, cost and turnaround time, and often involve complex interpretation rules before the results can be reported. A single-target PCR, carefully designed to specifically and exclusively amplify B pertussis DNA would, therefore, be preferable to current assays based on IS481 or multiple targets. Several real-time PCR assays designed to amplify non-IS481 single-gene targets have been described for the specific detection of $B$ pertussis (12-14). In the present study, we evaluated the performance of these PCR assays in parallel with a novel real-time PCR assay that targets the B pertussis porin gene and the widely used IS481-based PCR assay.

Bacterial strains and culture

\section{METHODS}

The reference panel was comprised of $B$ pertussis (American Type Culture Collection [ATCC] BAA-589, 9340 and 9797, and a clinical strain isolated at BC Children's Hospital [Vancouver, British Columbia] from a patient nasopharyngeal aspirate), B parapertussis (ATCC 15237 and a clinical strain isolated at the BC Centre for Disease Control [Vancouver, British Columbia]), B holmesii (ATCC 51541), B bronchiseptica (ATCC BAA-588), Haemophilus influenzae (ATCC 10211), Pseudomonas aeruginosa (ATCC 27853), Klebsiella pneumoniae (ATCC 13882), Staphylococcus aureus (ATCC 43300), Staphylococcus epidermidis (ATCC 12228), Streptococcus agalactiae (ATCC 13813), Streptococcus mitis (ATCC 6249), Streptococcus pneumoniae (ATCC 49619), Streptococcus pyogenes (ATCC 19615), Corynebacterium pseudodiphtheriticum (ATCC 10700), Mycoplasma pneumoniae (ATCC 29342), Chlamydophila pneumoniae (ATCC
VR-1310) and a clinical strain of Neisseria mucosa isolated at BC Children's Hospital. Bordetella species were streaked on charcoal agar medium (Oxoid) and grown at $37^{\circ} \mathrm{C}$ for $72 \mathrm{~h}$ in a humidified environment. Bacterial suspension was prepared in phosphate-buffered saline to a turbidity equivalent to a $0.5 \mathrm{McF}$ arland standard, titred by colony counting and cryopreserved at $-80^{\circ} \mathrm{C}$. The titred bacterial stocks were diluted in TE8 buffer (10 mM Tris, 1 mM EDTA; pH 8.0) and used directly in the PCR reactions. Other bacteria were grown on blood or chocolate agar plates (Oxoid) overnight at $37^{\circ} \mathrm{C}$ in a $5 \% \mathrm{CO}_{2}$ atmosphere, and a bacterial suspension was prepared in TE8 buffer to a turbidity equivalent to a $0.5 \mathrm{McF}$ arland standard. The suspension was further diluted 1:10 in TE8 before being used for PCR.

\section{Specimens}

A total of 107 nasopharyngeal wash specimens were used in the present study, including selected PCR-positive (by a SYBR Green PCR [15]) specimens since August 2009, and specimens submitted between September 2011 to October 2012 to the Microbiology and Virology laboratory of BC Children's Hospital for B pertussis PCR. Testing was performed exclusively on retrospective, residual samples that were stored at $-80^{\circ} \mathrm{C}$. To maintain patient anonymity, each sample was coded and all patient identifiers were removed to ensure that personnel involved in the present study were unaware of any patient information. Ethics approval was not considered to be necessary because studies that involve the secondary use of anonymous human biological materials are exempted from review by the local Research Ethics Board of the University of British Columbia. DNA from $0.2 \mathrm{~mL}$ nasopharyngeal wash specimens was extracted using the QIAsymphony virus/bacteria kit in an automated DNA extraction platform QIAsymphony SP (Qiagen, USA).

\section{PCR}

The titred bacterial suspensions and DNA extracts from 107 nasopharyngeal wash specimens were analyzed using Taqman real-time PCR or by SYBR Green PCR with the primers and probes shown in Table 1. For Taqman real-time PCR assays, $5 \mu \mathrm{L}$ of sample 
TABLE 3

Detection of Bordetella pertussis in nasopharyngeal samples from patients

\begin{tabular}{lccccc}
\hline & $\begin{array}{c}\text { IS481 } \\
\text { (Tatti et al [11]) }\end{array}$ & $\begin{array}{c}\text { BPTP } \\
\text { (Grogan et al [12]) }\end{array}$ & $\begin{array}{c}\text { BP283 } \\
\text { (Probert et al [13]) }\end{array}$ & $\begin{array}{c}\text { PRN } \\
\text { (Vincart et al [14]) }\end{array}$ & $\begin{array}{c}\text { POR } \\
\text { (in-house assay) }\end{array}$ \\
\hline True-positive samples, $\mathrm{n}$ & 20 & 19 & 19 & 19 & 20 \\
False-positive samples, $\mathrm{n}$ & 1 & 1 & 0 & 0 & 0 \\
True-negative samples, $\mathrm{n}$ & 85 & 86 & 87 & 87 & 87 \\
False-negative samples, $\mathrm{n}$ & 0 & 1 & 1 & 9 & 0 \\
Sensitivity, \% & 100 & 95 & 95 & 105 & 100 \\
Specificity, \% & 98.8 & 98.8 & 100 & 100 & 100 \\
\hline
\end{tabular}

${ }^{*}$ Samples were considered to be positive if the cycle threshold values were $\leq 40$ and typical amplification curves were observed. BPTP Bordetella parapertussis toxin promoter; POR Porin; PRN Pertactin

A

\begin{tabular}{|c|c|c|c|c|c|c|c|}
\hline \multirow{2}{*}{ Sample } & \multicolumn{6}{|c|}{$C_{T}$ values from different assays } & \multirow{2}{*}{ Sequencing } \\
\hline & POR & PRN & BP283 & BPTP & OMP & IS481 & \\
\hline 1 & 38.4 & 38.3 & 0 & 36.0 & $* 36.0$ & 30.2 & Pertussis \\
\hline 2 & $* 37.5$ & 0 & 38.1 & 0 & 34.5 & 31.6 & Pertussis \\
\hline 3 & 0 & 0 & 0 & $* 35.5$ & 0 & 32.2 & onchisentic \\
\hline
\end{tabular}

B

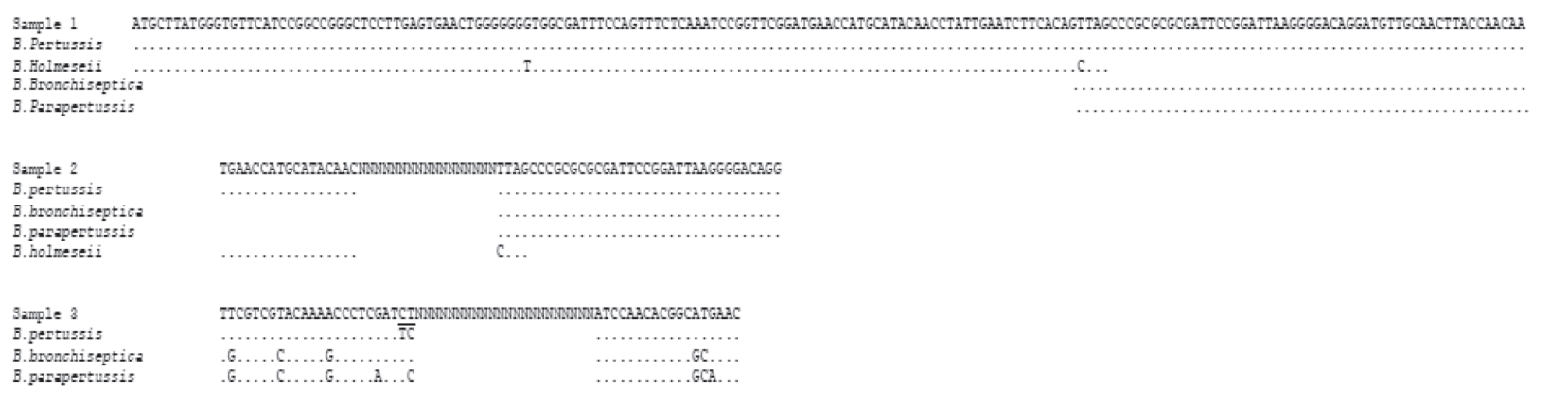

Figure 2) Further analysis of discrepant samples. A Table showing parallel results of various PCR assays and sequencing for three discrepant samples (*Polymerase chain reaction [PCR] products that were sequenced). B Alignment of sequences obtained from different PCR products with genome sequences from different Bordetella species (GeneBank accession nos. HE965805 [Bordetella pertussis], BX640433 [Bordetella parapertussis], HE965806 [Bordetella bronchiseptica] and DQ420073 [Bordetella holmesii]). Dots indicate homology with the derived sequences. For samples 2 and 3 , only partial sequences were obtained because these PCR products are very small in size. For sample 3, two bases right after the forward primer (underlined) indicate that the sequence is obtained from B bronchiseptica genome. $\mathrm{C}_{T}$ Cycle threshold; N Low-quality basecalls; OMP Outer membrane porin protein; POR Porin; PRN Pertactin

assay (15) is a SYBR Green-based, shared primer assay designed to amplify both $B$ pertussis and B parapertussis-specific DNA, but with different size PCR products that can subsequently be differentiated by their dissociation curves. When this PCR assay was applied to the panel of different Bordetella species and other respiratory bacteria, false-positive amplification was observed with B holmesii, B bronchiseptica, $S$ mitis and $S$ pyogenes, but the dissociation curves were distinct from that of $B$ pertussis and $B$ parapertussis strains (Table 2). Apart from this assay, none of the other assays showed any cross-reactivity with other bacteria tested in the present study that do not belong to the genus Bordetella. The analytical sensitivity of IS481 assay for B pertussis was much higher (by cycle threshold $>7$ ) than other assays. The assay detected all $B$ pertussis strains in the test panel, but also resulted in the false-positive detection of B parapertussis, B holmesii and B bronchiseptica strains, confirming the nonspecific nature of this target.

Among the single-target Taqman assays, the BPTP assay nonspecifically detected B bronchiseptica along with B pertussis strains, while the ptx-promoter assay, PT-P, designed in the present study lacked sensitivity and failed to detect all B pertussis strains. The BP283 assay was specific to $B$ pertussis but failed to detect two of the four $B$ pertussis strains tested. The PRN assay detected all $B$ pertussis strains but it weakly detected $B$ bronchiseptica at a relatively high concentration $\left(\geq 5.4 \times 10^{5} \mathrm{CFU} / \mathrm{mL}\right)$. In contrast, the newly designed POR assay did not exhibit any cross-reactivity with DNA from any of the non-B pertussis strains.
Based on these results, the IS481, BPTP, BP283, PRN and POR assays were selected for further analysis of clinical samples. Among the 107 nasopharyngeal wash specimens, $21(19.6 \%)$ samples were positive according to the IS481 assay, 20 (18.7\%) samples were positive according to the BPTP and POR assays, and 19 (17.7\%) samples were positive according to the BP283 and PRN assays (Table 3). Samples that produced discrepant results were further analyzed by sequencing the PCR products. There were three discrepant samples: a sample that was positive according to all assays except the BP283 assay; a sample that was missed by the PRN and BPTP assays; and a sample that was only positive using the BPTP and IS481 assays. Sequencing of PCR products confirmed that the first two samples were, in fact, $B$ pertussis, while the third sample was B bronchiseptica (Figure 2). Taking into account the definitive sequence identification, the performances of all five $B$ pertussis-specific assays were comparable, but the newly designed POR assay correctly detected all samples with a clinical sensitivity equal to that of IS481 assay. Based on a Probit regression analysis, the 95\% detection limit of the POR assay was $4 \mathrm{CFU} /$ reaction.

\section{DISCUSSION}

The diagnosis of whooping cough caused by B pertussis could be difficult, particularly at the early stages because the signs and symptoms of the disease closely resemble those of other common respiratory illnesses, such as those caused by Mycoplasma pneumoniae, Corynebacterium 
pneumoniae and adenoviruses. Moreover, other related Bordetella species, such as B parapertussis, B bronchiseptica and B holmesii, are also known to cause respiratory illness in humans, although generally with a milder clinical presentation $(3,8)$. Specificity of diagnostic and surveillance methodologies for $B$ pertussis is, therefore, critical for the effective management and control of pertussis disease. However, PCR testing for pertussis, which is now in widespread use, has variable specificity and needs further standardization and optimization $(1,9)$. In the present study, we aimed to identify or develop a highly specific and sensitive, real-time PCR assay for B pertussis that can replace the PCR assays based on IS481, which is a repeat element present in the genomes of different Bordetella species at variable copy numbers (5). We tested and compared the performance characteristics of both previously published and in-house developed PCR assays that target different genes and genomic regions specific to $B$ pertussis, in addition to that of IS481-based PCR assays. We observed remarkable variation in the specificity of different PCR assays while assessing a sample panel, comprised of reference strains of various Bordetella species. However, the sensitivity and specificity of these assays remained approximately $95 \%$ in the clinical samples.

The discrepant clinical sample results obtained by the different $B$ pertussis specific real-time PCR assays are consistent with those obtained using the ATCC panel of different Bordetella species. The BP283 assay, which failed to detect two known ATCC strains of

\section{REFERENCES}

1. Guiso N, Wirsing von Konig CH, Forsyth K, Tan T, Plotkin SA. The Global Pertussis Initiative: Report from a round table meeting to discuss the epidemiology and detection of pertussis, Paris, France, 11-12 January 2010. Vaccine 2011;29:1115-21.

2. Plotkin S. Aims, scope and findings of the global pertussis initiative Pediatr Infect Dis J 2005;24:S5-6.

3. Waters V, Halperin, S. Bordetella pertussis. In: Mandell GL, Bennett JE, Dolin R, eds. Mandell, Douglas, and Bennett's Principles and Practice of Infectious Diseases. Philadelphia: Elsevier Inc, 2010:2955-64.

4. Parkhill J, Sebaihia M, Preston A, et al. Comparative analysis of the genome sequences of Bordetella pertussis, Bordetella parapertussis and Bordetella bronchiseptica. Nat Genet 2003;35:32-40.

5. Tizolova A, Guiso N, Guillot S. Insertion sequences shared by Bordetella species and implications for the biological diagnosis of pertussis syndrome. Eur J Clin Microbiol Infect Dis 2012;32:89-96.

6. Register KB, Sanden GN. Prevalence and sequence variants of IS481 in Bordetella bronchiseptica: Implications for IS481-based detection of Bordetella pertussis. J Clin Microbiol 2006;44:4577-83.

7. Reischl U, Lehn N, Sanden GN, Loeffelholz MJ. Real-time PCR assay targeting IS481 of Bordetella pertussis and molecular basis for detecting Bordetella holmesii. J Clin Microbiol 2001;39:1963-6.

8. Mattoo S, Cherry JD. Molecular pathogenesis, epidemiology, and clinical manifestations of respiratory infections due to Bordetella pertussis and other Bordetella subspecies. Clin Microbiol Rev 2005; $18: 326-82$.
$B$ pertussis, also failed to detect one of the $B$ pertussis-positive clinical samples. The IS481 and BPTP assay, which detected a known ATCC strain of $B$ bronchiseptica, also produced one false-positive result among the clinical samples, which was eventually confirmed to be positive for B bronchiseptica by sequencing. The results of using the PRN assay on the ATCC panel suggests that this assay could also falsely detect $B$ bronchiseptica, particularly at bacterial concentrations $>10^{5} \mathrm{CFU} / \mathrm{mL}$ in clinical samples. The novel real-time PCR assay that targets the porin gene of $B$ pertussis demonstrated superior performance over all other B pertussis PCR assays tested in the present study.

The higher analytical sensitivity, but poor specificity of the IS481 PCR, is well described in the literature and is a generally accepted phenomenon $(5-7,11)$. However, an independent comparison of the most common single-target PCR assays for $B$ pertussis has not been reported to date. Therefore, the results of the present study could be useful for guiding clinical microbiologists in the selection of an appropriate real-time PCR assay for B pertussis. The new POR gene-based PCR assay described may serve as a valuable new tool for diagnostic laboratories seeking to improve the specificity of B pertussis detection, with sensitivity comparable with that of IS481 PCR assays.

DISCLOSURES: The authors have no financial disclosures or conflicts of interest to declare.

9. Dalby T, Fry NK, Krogfelt KA, Jensen JS, He Q. Evaluation of PCR methods for the diagnosis of pertussis by the European surveillance network for vaccine-preventable diseases (EUVAC.NET) Eur J Clin Microbiol Infect Dis 2013;32:1285-9.

10. Qin X, Galanakis E, Martin ET, Englund JA. Multitarget PCR for diagnosis of pertussis and its clinical implications. J Clin Microbiol 2007;45:506-11.

11. Tatti KM, Sparks KN, Boney KO, Tondella ML. Novel multitarget real-time PCR assay for rapid detection of Bordetella species in clinical specimens. J Clin Microbiol 2011;49:4059-66.

12. Grogan JA, Logan C, O'Leary J, Rush R, O'Sullivan N. Real-time PCR-based detection of Bordetella pertussis and Bordetella parapertussis in an Irish paediatric population. J Med Microbiol 2011;60:722-9.

13. Probert WS, Ely J, Schrader K, Atwell J, Nossoff A, Kwan S. Identification and evaluation of new target sequences for specific detection of Bordetella pertussis by real-time PCR. J Clin Microbiol 2008; $46: 3228-31$.

14. Vincart B, De Mendonca R, Rottiers S, Vermeulen F, Struelens MJ, Denis O. A specific real-time PCR assay for the detection of Bordetella pertussis. J Med Microbiol 2007;56:918-20.

15. Li Z, Jansen DL, Finn TM et al. Identification of Bordetella pertussis infection by shared-primer PCR. J Clin Microbiol 1994;32:783-9.

16. Burd EM. Validation of laboratory-developed molecular assays for infectious diseases. Clin Microbiol Rev 2010;23:550-76. 


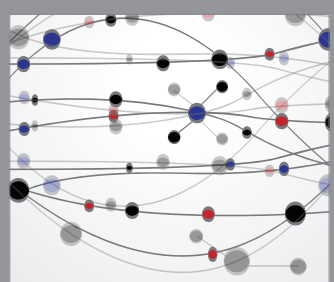

The Scientific World Journal
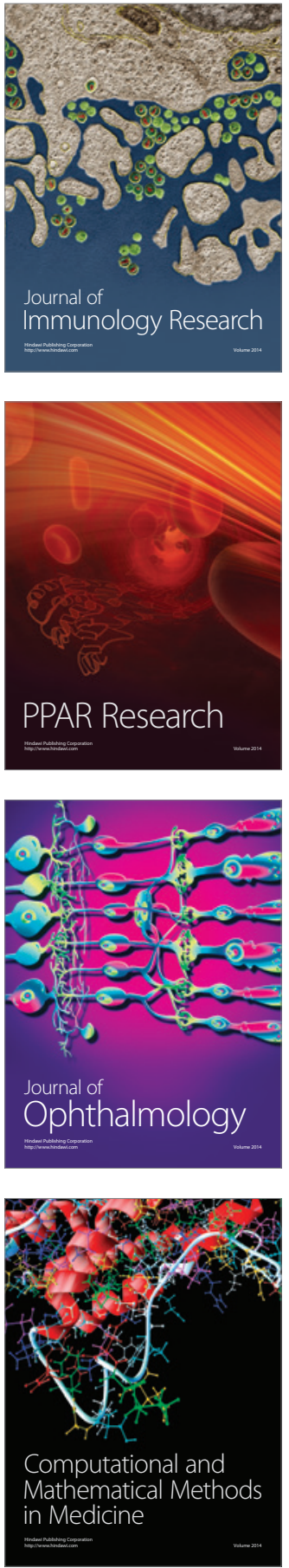

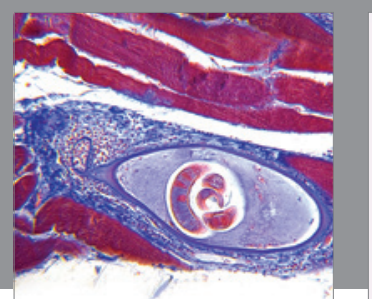

Gastroenterology Research and Practice

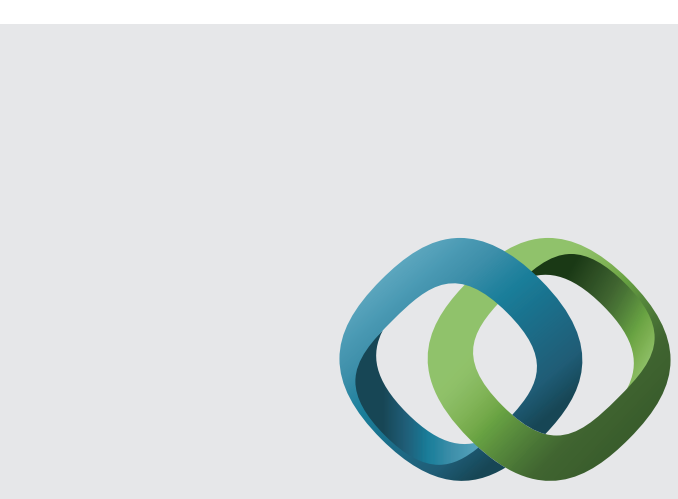

\section{Hindawi}

Submit your manuscripts at

http://www.hindawi.com
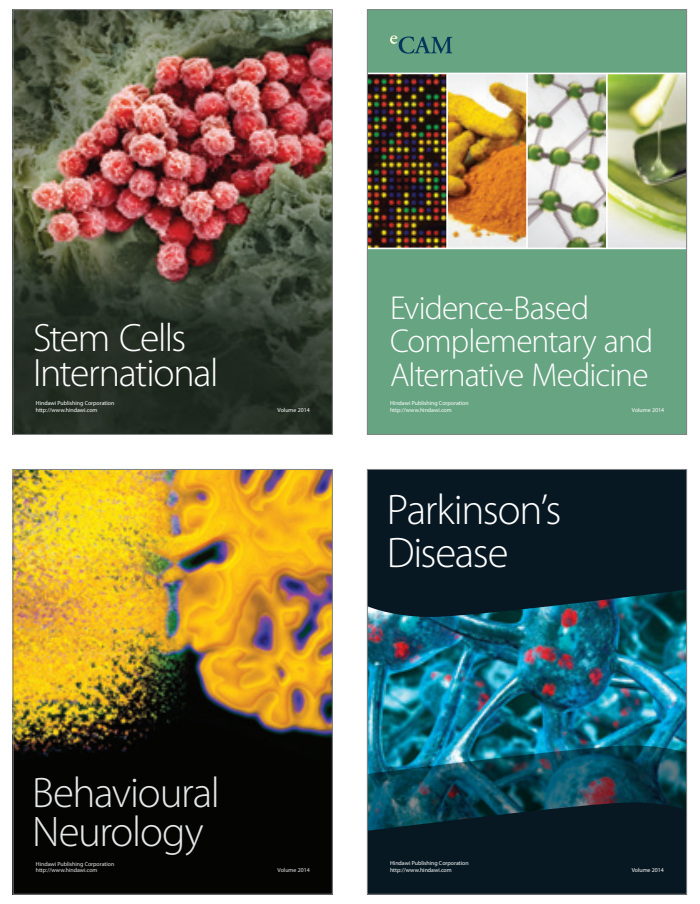
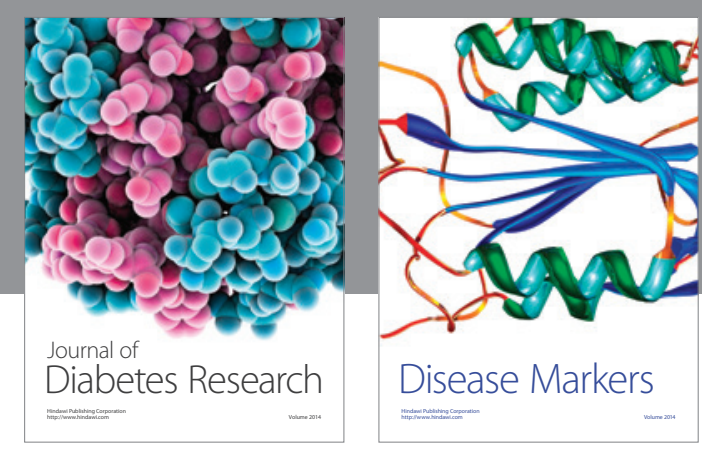

Disease Markers
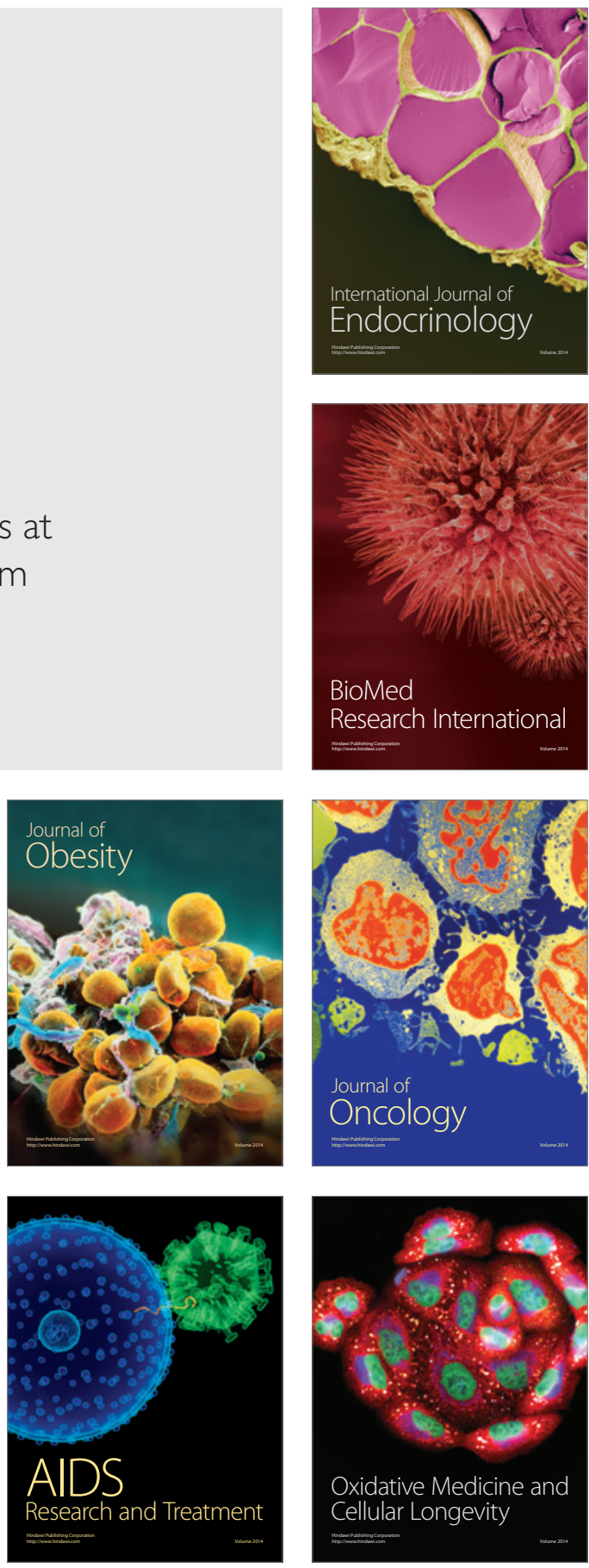